Institute of

Public Finance
NEWSLETTER

AN OCCASIONAL PUBLICATION OF THE INSTTTUTE OF PUBLIC FINANCE

\title{
Budget transparency of Groatian counties, cities and municipalities
}

\author{
KATARINA O'TT Institute of Public Finance \\ MiHAELA BRONIĆ Institute of Public Finance \\ MIROSLAV PETRUŠIĆI
}

This paper aims to analyse the openness, i.e. transparency of the budgets of local units in Croatia. ${ }^{2}$ The idea was to find out whether citizens have access to the 20I3 budget proposal, enacted budget and citizens budget on the websites of their respective local units. The analysis has shown that the level of openness of local budgets, notably in municipalities, is very low, and that few local units try to bring their budgets closer to citizens, while many of them have very poor websites or no websites at all (some municipalities, for example). Nevertheless, it is encouraging, that there are units with excellent websites. For more openness of the local budgets, it is necessary to reform the local unit system, to improve the co-operation of the Government and Ministry of Finance with the Croatian County Association and the associations of cities and municipalities in promoting the openness of their budgets, tighten the transparency control of the local units' budgets and step up the efforts of the units themselves to publish budget documents in a timely manner and to improve markedly the quality of the websites.

\section{INTRODUGTION}

A local unit's budget transparency implies the possibility that citizens can obtain information about their local unit's budgets that is: complete, relevant, correct, timely and presented in an understandable form (Bronić, Ott and Urban, 2012). If budgets are transparent, citizens can follow and analyse the information, as well as evaluate the authorities' political decisions. An open budget prevents reckless spending, fraud and abuses, enables citizens to call the authorities to account for specific actions, boosts confidence in the political system and, potentially, helps attract investments.

The transparency of local budgets can increase, stimulated by democratisation processes, political competition, fiscal crisis, media reporting on corruption, comparison with other local units and some external pressures, e.g. from the central government. While most of these factors are already at work in Croatia, one can only hope that there will be no factors hindering budget transparency, such as authoritarian local governments, incompetent local administration, but also disinterested and/or uninformed and corrupt media and citizens.

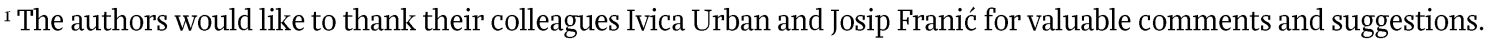
${ }^{2}$ In this paper, the term "local units" includes all counties, all cities and a sample of one hundred municipalities.
} 
In order to determine the state of budget transparency in local units, particularly in the context of the Open Government Partnership, of which Croatia is a member and under which it committed itself, among other things, to promote budget transparency, we embarked on a research study, the findings of which are presented in this paper.

We explored all the 20 counties, 127 cities and a sample of too out of 429 municipalities3. Our goal was to measure the level of openness of the local units' budgets for 2013. We therefore searched the Internet to find published budget proposals, enacted budgets and citizens budgets for 2013. We also assessed the accessibility and quality of their websites, trying to establish whether these local units publish the relevant documents on their own web pages or only in the official gazette, whether there is a direct link on their own websites to the budget documents and/or to the official gazette, how simple or complicated it is to find the budget documents, how efficient the search engines are, etc.

Our task was very complex, not only due to the large number of analysed local units but also due to the fact that some local units even had no websites; others had no search engines, or, if they had them, they were almost useless. Some units published budget documents in their own or in the relevant counties' official gazettes, but not directly on their own websites; some of these official gazettes either had no search engines or the engines were useless, and there were also broken links or links infected with viruses. Some of them even contained advertisements.

Despite the numerous difficulties, our analysis has yielded some very concrete results:

- The level of openness of the analysed units' budgets in 2013 is very low, especially in the case of municipalities, and it does not depend to a significant extent on the number of inhabitants, total operating revenues or operating revenues per capita.

- Very few local units make efforts to bring their budgets closer to citizens, i.e. publish citizens budgets.

- Many local units have very poor websites, and there are also municipalities with no websites at all (in our sample of too municipalities these are: Plaški, Zažablje, Viškovci, Dežanovac and Gornji Bogićevci).4

- Navigation on a large number of web pages is very difficult.

- It is encouraging that there are still units whose websites deserve to be recommended and pointed out as an example to others.

In the following text we will explain in greater detail the background to the Open Government Partnership, which has as its goal the promotion of transparency of local units' budgets, present the results of our analysis and conclude it with recommendations for improving the openness of the local units' budgets.

\footnotetext{
3 We examined the local units' websites from 6 March to I5 April 20I3. The sample of municipalities was selected by determining the percentage of municipalities from each county in the total number of municipalities. Then we made a random selection of municipalities from the counties, placed them in alphabetical order and assigned an ordinal number to each of them. On the website Random.org, we generated as many random numbers as there were municipalities selected from a given county for the sample. Then we included in the sample the municipalities the ordinal numbers of which have been drawn. As a result, the largest number of municipalities in the sample were from the Split-Dalmatia County (nine), and the smallest from the Lika-Senj and Požega-Slavonia Counties (two from each of them). The names of the analysed municipalities are available at request. In the meantime, the municipality of Popovača has become a city, so that there are currently i28 cities (including Zagreb which as the country's capital enjoys a special status of both city and county) and 428 municipalities in Croatia. However, for the purposes of this paper, Popovača has not been included among cities, neither has it been drawn for the sample of municipalities.

4 The websites of these five municipalities do not even exist in the Government's address book, except for Plaški, for which the address exists but is inactive. It should be noted that there are municipalities in the sample with an even smaller number of inhabitants than these five municipalities, but they still have websites, for example Kukljica, Janjina and Zadvarje. Admittedly, there is no municipality in the sample with operating revenue lower than those reported by Zažablje. The fact that as many as $5 \%$ of the observed municipalities do not have websites again points to the need to reform the local unit system.
} 


\section{OPEN GOVERNMENT PARTNERSHIP}

In 2012, the Republic of Croatia joined the Open Government Partnership (OGP), a global initiative to ensure effective progress in the areas of transparency of the work of public authority bodies, empowering citizens and involving citizens and the civil society in the policy-making process, the fight against corruption and the use of new technologies to improve the quality of public services to citizens.

Under the Action Plan for the Implementation of the OGP for the period 2012-13, Croatia undertook to give recommendations and instructions to all local units to publish, in a timely manner, on their official websites the following key budget documents:

- $\quad$ budget proposal - when it is submitted to the representative body by the executive body;

- enacted budget - after it has been voted on by the representative body; and

- mid-year and end-year reports on budget execution - when the executive body submits them to the representative.

The Ministry of Finance has indeed, in its Instructions for Drawing up the Budgets of the Units of Local and Regional Self-government, 2013-15, issued such a guideline. 5

\section{THE LEVEL OF OPENNESS OF THE 2OI3 LOGAL BUDGETS}

In our analysis, the level of local budget openness ranges between o and 3 and is measured by assigning one point to each observed local unit for each of the following 2013 budget documents published on the website: budget proposal, enacted budget and citizens budget.

Budget proposal is a document in which an executive body (a county prefect, a city mayor or a municipality mayor) plans the local unit's revenues and expenditures for the next year; the document is submitted to a representative body (a county assembly, city council or municipality council). After its adoption by the representative body, the budget proposal becomes the enacted budget. The demonstration of these documents by the executive body to the public in a simple form (a brochure, presentation, etc.) constitutes a citizens budget.

The reason why we analysed the publication of budget proposals, enacted budgets and citizens budgets was that these documents were chronologically the first on the list of budget documents recommended for publication by the Ministry of Finance under the OGP Action Plan. The publication of mid-year and end-year reports on budget execution will be assessed subsequently.

We were not very strict in assessing whether a document has been published or not, holding that the term published budget proposal included everything that has been posted on a local unit's website and that could be seen as a proposal, even documents from or for the meetings in which they were or are to be discussed. A published enacted budget is considered to be not only the one available on a particular local unit's website, but also the one for which there is a clearly indicated link to the enacted budget in an official gazette. If there is no link on the local unit's website to the enacted budget in the official gazette, for the purposes of this analysis, the budget will be considered not published. A published citizens budget is any piece of material (brochure, presentation, etc.) available on a local unit's website, explaining the content of the budget proposal or enacted budget to citizens in a simple manner.

${ }^{5}$ See Section 4.5.I Publishing key budget documents. 


\section{Chart I}

Local units by level of budget openness, 2013, in \%*

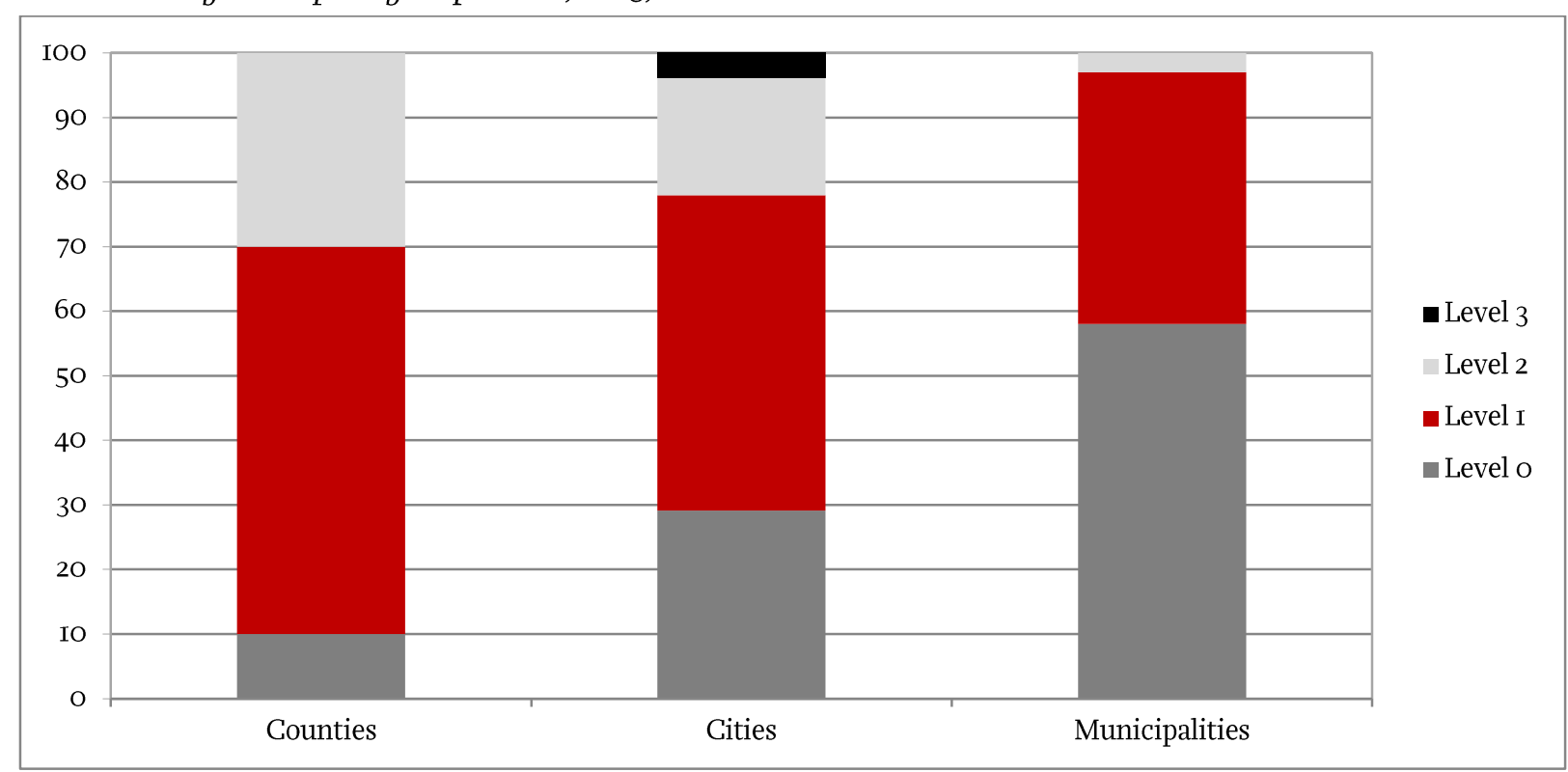

* Out of possible 3, the average level of openness of the 2013 budgets stood at I.2 for counties, I for cities and 0.5 for municipalities.

In terms of percentage, the situation is expectedly the worst in municipalities - in nearly $60 \%$ of sampled municipalities the level of budget openness is zero. This implies that they have not published any of the observed documents (budget proposal, enacted budget or citizens budget) on their websites. Prevailing among counties and cities are those with only one of the documents published on their websites. ${ }^{6}$

\section{Chart 2}

Local units which have published the observed 2013 budget documents on their websites, in \%

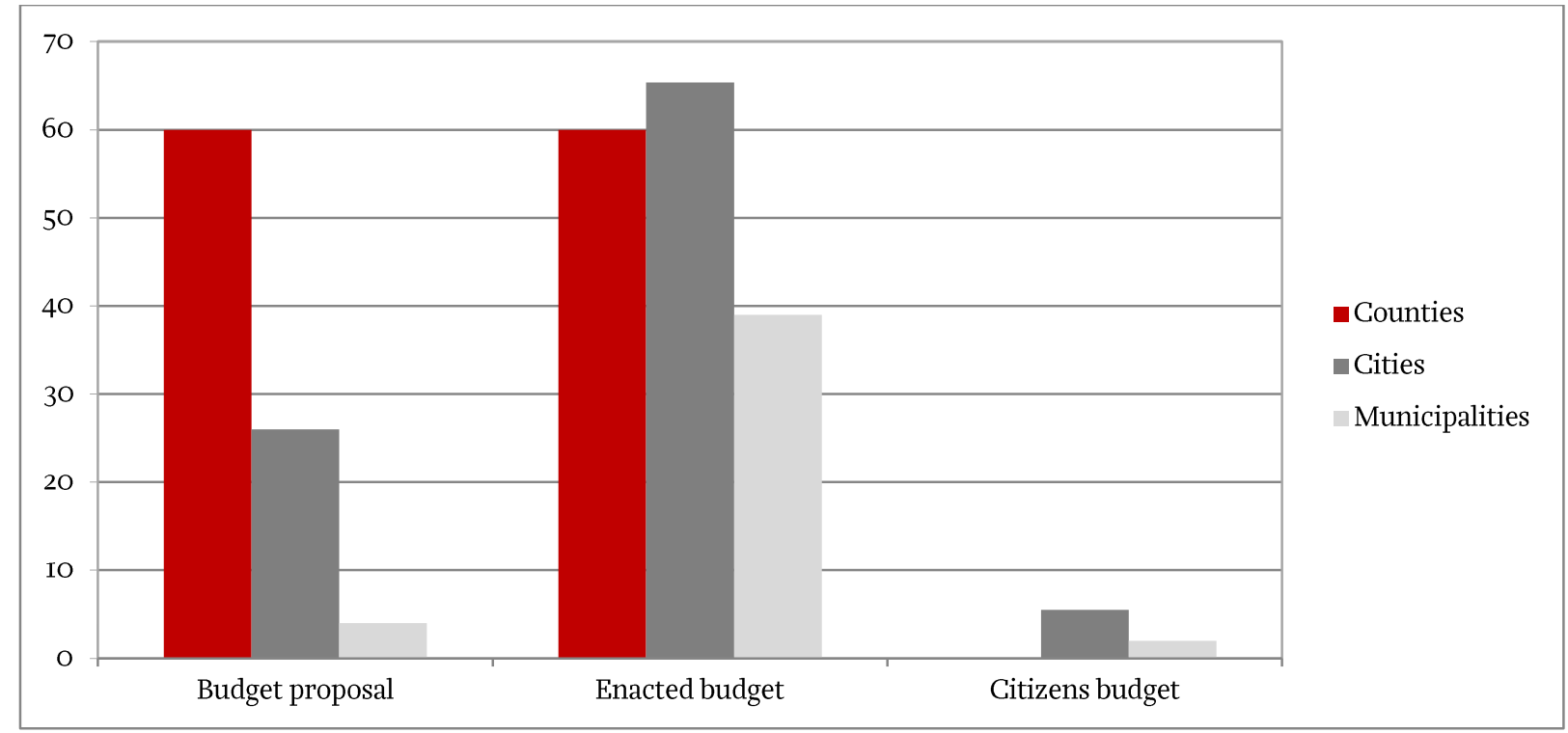

${ }^{6}$ The largest percentage of counties, followed by cities, and only three municipalities from the sample (Krnjak from the Karlovac County, Matulji from the Primorje-Gorski Kotar County and Vrbanja from the Vukovar-Srijem County) have published two budget documents each. All the three documents were published by only five cities: three from the Istria County (Buzet, Labin and Pazin), and two from the Primorje-Gorski Kotar County (Opatija and Rijeka). 
Enacted budgets have not been published on the websites of $40 \%$ of counties, $35 \%$ of cities and $60 \%$ of municipalities. It is noteworthy that part of municipalities and cities publish their enacted budgets in the county official gazettes only, and not on their official websites. The municipalities and cities with valid direct links on their websites to the enacted budget published in a municipality, city or county gazette, are considered to be publishing it.

Only counties have published on their websites both the budget proposals and enacted budgets for 2013 in equal percentages $(60 \%)$. As concerns cities and municipalities, the number of those with published enacted budgets exceeded the number of those with published budget proposals (the score was $65 \%$ to $25 \%$ for cities and $39 \%$ to $4 \%$ for municipalities). This actually means that citizens are in most cases presented with a fait accompli, because they have no influence on discussions about the budget proposal and are only informed about the budget once it has been voted on.

\section{Gitizens budget}

Thanks to international initiatives and international organisations ${ }^{7}$ dealing with budget openness, there is a consensus on the need to publish the following eight key budget documents: pre-budget statement (i.e. economic and fiscal policy guidelines), budget proposal, enacted budget, monthly reports, mid-year report, endyear report, state audit report and the simplified version of these documents (citizens budget).

The citizens budget (citizen's guide to the budget or budget in a nutshell) is published simultaneously with the budget documents referred to therein. As these documents are very extensive, complex and almost incomprehensible to the layman, the citizens budget should help the public understand how budget revenues are collected, how budget expenditures are planned and how large the budget deficit/surplus is. Only when this is understood, can the public be included in discussions within the budgeting process and have some influence on government accountability.

The citizens budget must be published and distributed as widely as possible simultaneously with the documents to which it relates (e.g. budget proposal or enacted budget). As concerns state budgets, governments disclose them in various shapes and sizes (from two pages, as in South Africa to about a hundred pages in Estonia). The situation is similar with the budgets of local units.

The citizens budget must be an objective document rather than the one spreading the political propaganda. It must be written in a simple and citizen-friendly language with easy-to-survey tables and charts. It must be comprehensive, relevant, and reliable and published in a timely manner ${ }^{8}$.

In accordance with the OGP Action Plan, local executive authorities should publish citizens budgets at least together with their budget proposals, enacted budgets and mid-year and end-year reports on budget execution, provided, of course, that these documents are published as well.

Local units in most cases do not care about clarifying their budgets to citizens, i.e. they do not publish citizens budgets. Despite the recommendation of the Ministry of Finance, given in the afore mentioned Instructions for Drawing up the Budgets, to publish the citizens budget, no county has published the 2013 citizens budget, while only two out of a hundred sampled municipalities and only seven cities have done so. These municipalities include Križ and Brdovec (both from the Zagreb County). ${ }^{9}$ In the group of cities, citizens budgets were published in Ivanić-Grad, Opatija, Rijeka, Županja, Buzet, Labin and Pazin. As for Novska, there is information that the citizens budget has been sent to citizens by post, but it is not available on the website. ${ }^{\text {IO }}$

\footnotetext{
7 The most prominent international initiatives include the already mentioned Open Government Partnership (OGP), Global Initiative for Fiscal Transparency (GIFT) and Global Movement for Budget Transparency, Accountability and Participation. The international organisations include OECD, IMF and World Bank.

${ }^{8}$ There is abundant literature on citizens budgets, explaining their purpose and importance and providing instructions for their compilation, as well as examples of best practices (e.g. IBP, 2OI2, and Petrie and Shields, 20I2).

9 The municipalities of Križ and Brdovec also published citizens budgets in 2012 and 2010 respectively. Some municipalities published citizens budgets in certain years before 20I3: Velika Kopanica from the Brod-Posavina County in 2009 and Bizovac from the Osijek-Baranja County in the years 2009-I2.

Io Some of these cities have published citizens budgets occasionally; others have done so for a number of years, for example Rijeka and Županja. Some cities did not publish the 2013 budget, but used to do so in previous years (Vrbovec, Varaždin, Crikvenica and Omiš). Two cities deserve to be singled out: Rijeka, which provides on its website an educational game in which citizens can formulate the budget themselves and Buzet, which offers citizens on its website the opportunity to participate in budget formulation.
} 
It remains to be hoped, however, that the situation will improve in the years to come and that the number of local units publishing the citizens budget will increase. Indeed, the Ministry of Finance has, although with a considerable delay, prescribed within the commitments under the OGP Action Plan, a uniform format of the citizens budget intended for local units and recommended that they should publish it.

\section{WHAT DETERMINES THE LEVEL OF OPENNESS OF THE LOGAL UNITS' BUDGETS IN CROATIA?}

Using linear regression analyses, we tried to determine whether there is a correlation between the openness of local units' budgets in Croatia and some of the variables usually observed in literature (e.g. Wehner and Renzio, 2013 and Carlitz et al., 2009). Taking into account data availability, we tried to determine the correlation between the openness of 2013 local budgets and the population, total operating revenues and operating revenues per capita in 2011.

The analyses have shown that there is no statistically significant correlation between the openness of the budgets of counties, cities and municipalities and the observed variables (population, total operating revenues and operating revenues per capita)."I While there is a slight statistical correlation between the openness of cities' budgets and population and total operating revenues, there is no such correlation between the openness of cities' budgets and operating revenues per capita. This means that cities with larger populations and larger total operating revenues typically have slightly greater budget openness, but larger per capita revenues do not necessarily mean better transparency of city budgets. Nevertheless, it is evident that cities with the highest level or budget transparency also have slightly larger operating revenues per capita, e.g. Opatija (HRK 7,26I), Buzet (HRK 6,157), Pazin (HRK 5,590), Labin (HRK 5,I46) and Rijeka (HRK 4,793). For comparison purposes, the average operating revenue per capita for all the cities stands at about HRK 3.500 (from HRK I,O74 in Kutjevo to HRK9,374 in Novigrad.)

Although the analysis does not suggest any significant statistical correlations, it is obvious that most municipalities with low operating revenues have a o level of budget openness. However, of three municipalities with level 2 budget transparency, only one (Matulji) has extremely high operating revenues of HRK 58.2m, while the other two are not conspicuous for their large revenues (Krnjak with HRK 4.8m and Vrbanja with HRK IOm). For comparison' sake, the operating revenue average for all the municipalities stands at HRK 7.2m (from HRK 759,0oo in Zažablje to HRK 58.2m in Matulji).

In some future research which will cover a longer period of time, it may be possible to determine the influence of some additional variables, e.g. revenues from aid, indebtedness, political polarisation, competition among political parties in the representative bodies, competition between the executive and representative bodies, duration of the term of office and the level and type of education of municipality and city mayors and county prefects, regional origin (continental or Adriatic Croatia), etc.

\section{ACGESSIBILITY OF THE LOCAL UNITS' WEBSITES}

Establishing and maintaining an accessible website can be a demanding and expensive exercise, especially in small and low-income local units. However, the websites of many large and better-off local units often do not allow easy navigation. Even professional researchers, knowing exactly what they look for and where they can find it, are often faced with difficulties, not to speak of „ordinary” interested citizens with little knowledge of the budget. We therefore assumed that, unless the budget is on the homepage, citizens would use the search engine. Two counties (Lika-Senj and Šibenik-Knin) do not have search engines on their websites. On the websites of as many as 12 counties, it is very difficult to find budget documents by means of the search engine, while in only three counties (Krapina-Zagorje, Požega-Slavonija and SplitDalmatia) it is relatively easy to find these documents in the official gazettes using the search engines. In

\footnotetext{
II As concerns municipalities, the non-existence of a statistically significant correlation may be due to the fact that most municipalities already have a zero level of budget openness, meaning that they published none of the observed budget documents for 2013.
} 
as little as three counties (Krapina-Zagorje, Primorje-Gorski Kotar and Istria), the county gazettes have their own search engines.

If the most accessible county websites were selected then these would be the websites of the Istria and Krapina-Zagorje Counties, due to the ease of navigation, and the Primorje-Gorski Kotar County, for the well-designed official gazette website.

Compared with the websites of the counties, cities' websites are worse in some segments, but better in others. But the quality of the websites of most observed municipalities is extremely low. The websites of only half of municipalities have search engines, and in three-fourths of municipalities it is difficult to find budget documents on the website by means of the search engine. Less than $40 \%$ of the websites of municipalities have links to the official gazettes, and as much as $97 \%$ of them provide very poor access to the documents in the gazettes using search engines. Only 1.4\% of official gazettes have their own search engines.

The municipalities Bizovac (Osijek-Baranja County), Ervenik (Šibenik-Knin County) and Selca (SplitDalmatia) stand out for easy website navigation.

In addition to difficulties in finding and accessing the budget documents, some local units publish their budget documents undated, so that it is not clear whether a document is a budget proposal or the enacted budget. Moreover, they publish their official gazettes undated and unnumbered and some official gazette numbers are missing. There are local units which have not published the official gazette for years; the websites of some units have not been updated for quite a long time or they were „under construction” for as long as two months. Navigation through some websites is very slow, and broken links on some of them are commonplace. Some local units even have some of the budget documents posted on their websites, but instead of directly, they can only be accessed through Google.

\section{Chart 3}

Enacted budgets of local units published on the official websites and in the official gazettes, in \%

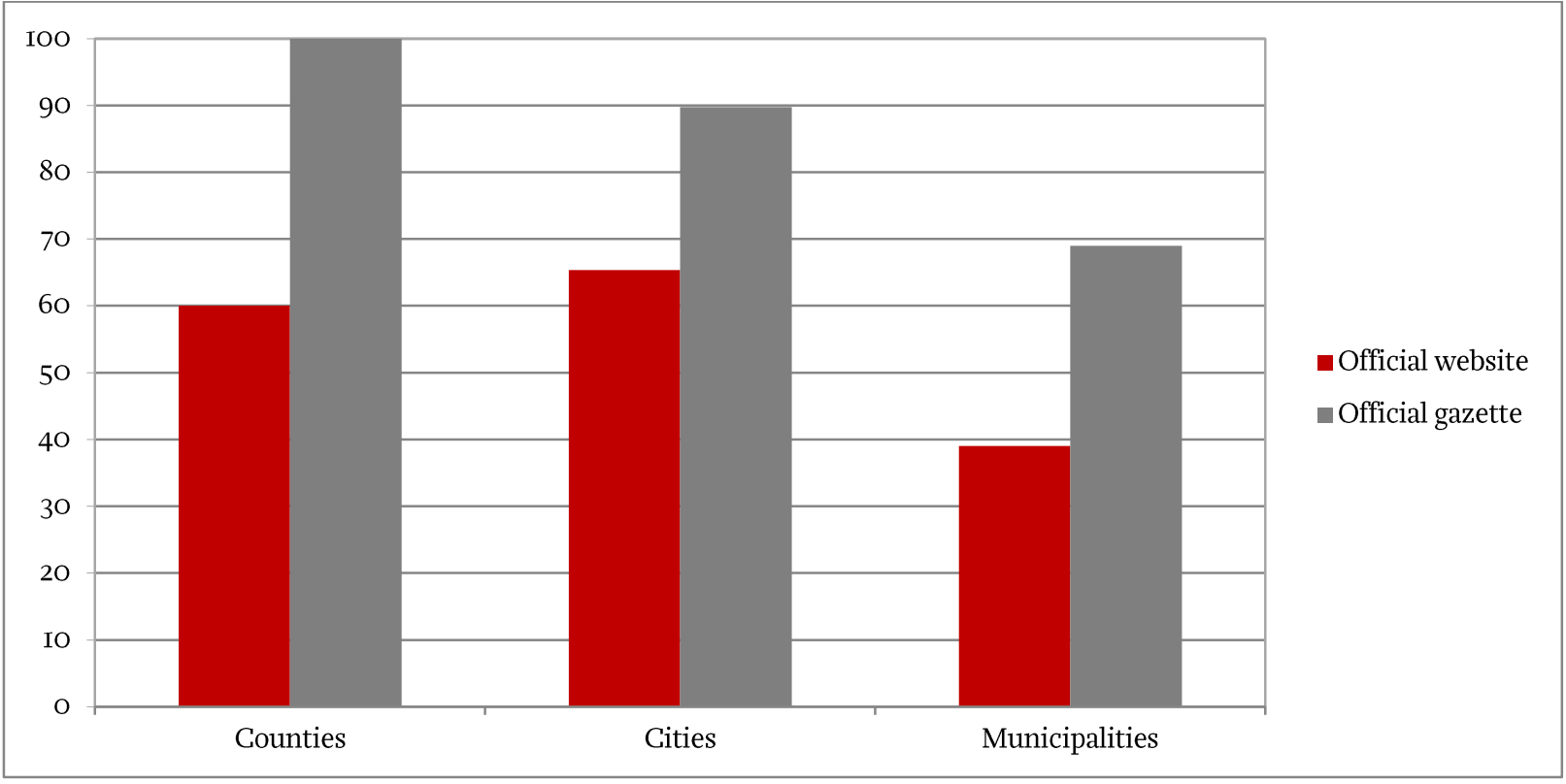


Chart 3 shows that a far higher percentage of the enacted budgets of counties ${ }^{12}$, cities and municipalities are published in the official gazettes than on these local units' websites. ${ }^{13}$ The transparency of the local units' budgets could be significantly improved if there were a direct link on a particular unit's website to the enacted budget posted in the official gazette.

\section{HOW TO INCREASE THE TRANSPARENCY OF LOCAL BUDGETS?}

The analysis has shown that the level of transparency of the local units' budgets is not satisfactory and that many things can and must be improved. It is always possible, of course, that the situation is better than suggested by the analysis, because some of the observed documents may be disclosed on the Internet, but we were not able to find them. However, this means that an average citizen would also have difficulties in finding such documents, which is why the budget transparency of those local units is questionable.

As with the analysis of all other issues relevant for local units, the conclusion stands that there are too many local units, especially municipalities, which are unable to meet even the basic criteria (i.e. to have and maintain websites and publish budget documents). A reform of the local unit system is simply a must, and the longer it is delayed the more serious its consequences will be, both for budget transparency and the prosperity of not only the local units but also the country as a whole.

Due to their (at least for the time being) declarative independence, neither the Government nor the Ministry of Finance can impose any special requirements on local units, but can only make certain recommendations to them. Therefore, they should intensify their cooperation with the Croatian County Association and the associations of cities and municipalities, and these associations should encourage their members to promote transparent budgeting. Despite the independence of the local units, which is highly questionable and actually only pro forma, taking into account their dependence on the central government's financial assistance, the Ministry of Finance should find better ways to encourage transparency in their budgeting practices.

After all, Article 12 of the Budget Act already prescribes the obligation of local units to publish their enacted budgets in the official gazettes, complete mid-year and end-year reports on budget execution on their websites and, additionally, parts of these reports in the official gazettes. The Act should be amended in the way that the entire budget proposal should be published on a local unit's website, and that the entire enacted budget should be disclosed both in a local unit's official gazette and on its website, or that there is a clearly indicated direct link on the homepage of a local unit's website to the website of the official gazette in which the enacted budget has been published. Moreover, the Ministry of Finance should check whether the local units publish their budget documents in accordance with the provisions of the Act and should take measures against those which fail to do so.

In addition to enacted budgets, local units should also publish budget proposals. Thus, citizens could and should be involved in the budget preparation process instead of being presented with a fait accompli.

It is especially important that as many local units as possible start publishing citizens budgets. Although this publication is crucial to citizens, as it helps them better understand budget documents, and although the Ministry of Finance has issued the appropriate instructions to this effect for the local units, the number of local units publishing this document is practically negligible.

\footnotetext{
${ }^{12}$ The Osijek-Baranja County does not have an official gazette on the Internet, but it does have a „Register of Applicable Regulations and Other Legal Acts" which includes the enacted budgets.

${ }_{13}$ The first column includes local units which have disclosed the enacted budgets on their websites or put a direct link to these documents in the official gazettes. The second column features all local units with enacted budgets published in the official gazettes. Both columns include local units which have on their websites clearly indicated links to the budget in the official gazette.
} 
If they really want to help citizens gain access to budget documents and participate in deciding on budgets, local units should considerably improve the quality of their websites. This would include posting direct links to the budget documents on the homepages, regardless of whether these documents have been published on a local unit's website or in its official gazette or the official gazette of a relevant county. It is also necessary to raise the efficiency of the website search engines of local units and official gazettes, to provide regular updates of the websites and ensure that all documents are dated.

The Croatian Government should, in a new OGP Action Plan for 20I4-15, lay greater emphasis on the transparency of local units' budgets. This could be one of the most effective steps towards achieving the OGP's goal to ensure „noticeable progress in the areas of transparency of the work of public authorities, empowering citizens and involving citizens and the civil society in the policy-making process, the fight against corruption and the use of new technologies to improve the quality of public services to citizens".

\section{REFERENGES}

Bronić, M., Ott, K. and Urban, I., 2012. Local budget transparency: the case of 33 Croatian cities. Financial Theory and Practice, 36 (4) 355-371.

Carlitz, R. et al., 2009. Budget Transparency around the World: Results from the 2008 Open Budget Survey. OECD Journal on Budgeting, 7 (2), I-17.

Croatian Bureau of Statistics. http://www.dzs.hr/default_e.htm

Global Initiative for Fiscal Transparency. http:/ /fiscaltransparency.net/

Global Movement for Budget Transparency, Accountability and Participation. http:/ /www.globalbtap.org/

Government of RC, 2012. Action Plan for the Implementation of the Initiative Open Government Partnership in the Republic of Croatia for period 20I2-2O13. Zagreb: Government of RC.

IBP, 2012. The Power of Making It Simple: A Government Guide to Developing Citizens Budgets. Washington: International Budget Partnership.

Ministry of Finance of RC, 20I2. Upute za izradu proračuna jedinica lokalne i područne (regionalne) samouprave za razdoblje 2013. - 2015. Zagreb: Ministry of Finance.

Ministry of Finance of RC, 2013. Jedinstveni format vodiča za građane uz proračune jedinica lokalne $i$ područne (regionalne) samouprave. Zagreb: Ministry of Finance.

Ministry of Finance. http://www.mfin.hr/en

Office for Cooperation with NGOs. http://www.uzuvrh.hr/defaulteng.aspx

Open Government Partnership. http://www.opengovpartnership.org/

Petrie, M. and Shields, J., 20I2. Producing a Citizens' Guide to the Budget: Why, What and How? OECD Journal on Budgeting, IO (2), I-I4.

Ramkumar, V. and Shapiro, I., 2010. Guide to Transparency in Government Budget Reports: Why are Budget Reports Important, and What Should They Include? Washington: International Budget Partnership.

Ramkumar, V. and Shapiro, I., 20Io. Guide to Transparency in Government Budget Reports: How Civil Society Can Use Budget Reports for Research and Advocacy. Washington: International Budget Partnership.

Random.org. http://www.random.org/

Wehner, J. and Renzio, P., 2013. Citizens, Legislators, and Executive Disclosure: The Political Determinants of Fiscal Transparency. World Development, 4I, 96-108.

Zakon o proračunu, NN 87/o8, 136/12. Zagreb: Narodne novine. 